70 巻 692 号 $(2004-4)$

\title{
大型車のロール特性を考慮した車両運動特性の実験的検討*
}

\author{
高野修一*1, 鈴木真弘*1, 永井 正夫*2 \\ 谷口哲夫*3, 波多野 忠*3
}

\section{Experimental Analysis of Dynamic Characteristics of a Large Vehicle Considering Its Roll Characteristics}

\author{
Shuichi TAKANO*4, Masahiro SUZUKI, Masao NAGAI, \\ Tetsuo TANIGUCHI and Tadashi HATANO
${ }^{* 4}$ Division of Mechanical Systems Engineering, The Graduate School of Technology, Tokyo University of Agriculture and Technology, 2-24-16 Naka-cho, Koganei-shi, Tokyo, 184-8588 Japan

\begin{abstract}
Accidents involving of large vehicles such as buses and trucks are often caused by rollovers. Roll motions affects dynamics of large vehicles more than that of passenger cars because of their high center-of-gravity heights. In this paper, a 4-ton truck is used as an experiment vehicle in order to determine its plane and roll motion characteristics. Every experiment is conducted for two different load conditions in order to simulate the realistic operating condition of a truck, and the effects of the vehicle's load on its motions are determined. The results from both static and dynamic experiments are compared to see if the vehicle's reaction in actual driving differs from that of a static vehicle. Also, simple mathematical models are used to determine the relationship between the plane and roll motions of the vehicle.
\end{abstract}

Key Words: Automobile, Maneuverability, Transient Response, Vehicle Dynamics, Truck, Commercial Vehicle, Roll

\section{1. 緒}

近年, 高速道路の整備改善に伴いトラック・バスな どが高速で走行する機会が増加している.これら大型 車の操縦の難しさの原因として,積載量に応じて車両 の挙動が大きく変化することが挙げられる(1),2.特に トラックは多量の積荷を積載することにより重心位置 が高くなり，ロール運動が乗用車に比べで(3)(4)過多と なる傾向にある.しかし過去に大型車の静的なロール 運動の分析 (5),(6) は行われているが, 実際の使用状況を 考慮した車雨運動の動的解析はあまり行われていない。 だがこれらの車両の走行時における挙動を理解するこ

* 原稿受付 2003 年 9 月 11 日。

*1 正員, 東京農工大学大学院工学研究科 (酸 184-8588 小金井市 中町 2-24-16).

*2 東京農工大学工学部.

*3 (独) 交通安全環境研究所 (画 182-0012 調布市深大寺東町 742-27).

E-mail:y1833201@gc.tuat.ac.jp
とは, 運用·安全面において大変重要である.そこで 本研究では,実車を用いてロール運動を始めとする走 行中のトラックの挙動,また積載量により変化する重 心高がそれらにおよぼす影響を検討する。また,ロー ルを含めた車両運動モデルを用い,これらの要素を論 理的に説明する.

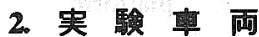

実験車両として, 図 1 の平ボデー, 後軸ダブルタイ

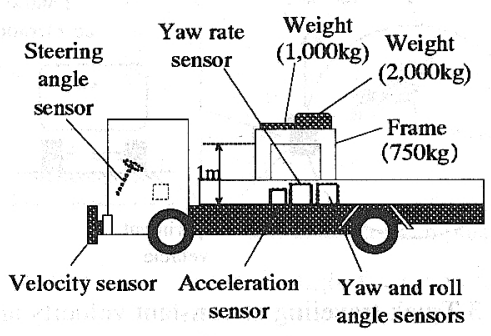

Fig. 1 Experiment vehicle 
Table 1 Vehicle parameters

\begin{tabular}{|c|c|c|c|c|}
\hline \multirow{2}{*}{ DEFINITION } & \multirow{2}{*}{ SYMBOL } & \multirow{2}{*}{ UNIT } & \multicolumn{2}{|c|}{ VALUE } \\
\hline & & & WNO LOAD & W/LOAD \\
\hline Vehicle mass & $m$ & $\mathbf{k g}$ & 4660 & 7660 \\
\hline Sprung mass & $m$, & $\mathbf{k g}$ & 4660 & 7660 \\
\hline Wheelbase & $l$ & $\mathbf{m}$ & 3.73 & 3.73 \\
\hline Gravitational acceleration & 8 & $\mathrm{~m} / \mathrm{s}^{2}$ & 9.81 & 9.81 \\
\hline Roll moment arm & h, & m & 0.4813 & 0.9499 \\
\hline Yaw moment of inertia & $I$ & $\mathrm{~kg} \mathrm{~m}^{2}$ & 16001 & 26364 \\
\hline Roll moment of inertia & $I_{\phi}$ & $\mathrm{kg} \mathrm{m}^{2}$ & 5333 & 12854 \\
\hline Distance from front axle to c.g. & $l_{f}$ & m & 1.716 & 2.056 \\
\hline Distance from rear axle to c.g. & $i$, & $\mathbf{m}$ & 2.014 & 1.674 \\
\hline Linear cornering stiffness per front tire & $k_{f}$ & $\mathrm{~N} / \mathrm{rad}$ & 26530 & 30200 \\
\hline Linear cornering stiffness per rear tire & $k_{r}$ & $\mathrm{~N} / \mathrm{rad}$ & 39500 & 60000 \\
\hline Total roll stiffness & $K_{0}$ & $\mathrm{~N} \mathrm{~m} / \mathrm{rad}$ & 409675 & 333356 \\
\hline Roll damping coefficient & $c$ & $\mathrm{~N}$ m s/rad & 20000 & 20000 \\
\hline Lateral force per front (rear) tire & $Y_{f}\left(Y_{r}\right)$ & $\mathbf{N}$ & - & - \\
\hline Vehicle velocity & $v$ & $\mathrm{~m} / \mathrm{s}$ & - & - \\
\hline Front steer angle & $\delta$ & deg & . & - \\
\hline Side-slip angle & $\beta$ & deg & - & - \\
\hline Yaw rate & $r$ & $\mathrm{deg} / \mathrm{s}$ & - & - \\
\hline Roll angle & $\phi$ & deg & - & - \\
\hline Lateral acceleration & $a_{a c c}$ & $\mathrm{~m} / \mathrm{s}^{2}$ & $\therefore$ & - \\
\hline
\end{tabular}

ヤの4 トン積みトラックを用いる. 実際の使用状況に おける積載条件による重心高の変化を想定し, 実験車 両の荷台の床上に台座を設置し, 台座上に $3000 \mathrm{~kg}$ の 重りを固定した状態を「積載時」，台座のみの状態を 「非積載時」と定義して各実験を行う。実験車両およ び使用したタイヤの各積載条件における諸元を表 1 に 示す.

\section{3. 実医}

$3 \cdot 1$ 頃斜台および定常円旅回実験定常状態 での横向き加速度に対する車体ロール角を求めるため に, 傾斜台実験および定常円旋回実験を行う。両実験 の概要をそれぞれ図 $2 ， 3$ に示す．傾斜台実験では実

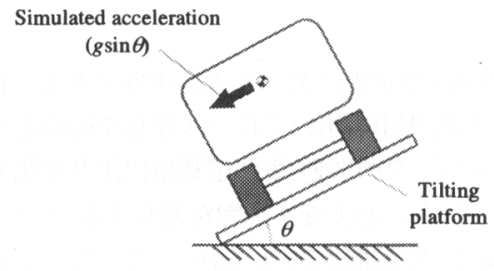

Fig. 2 Simulating lateral acceleration on tilting platform

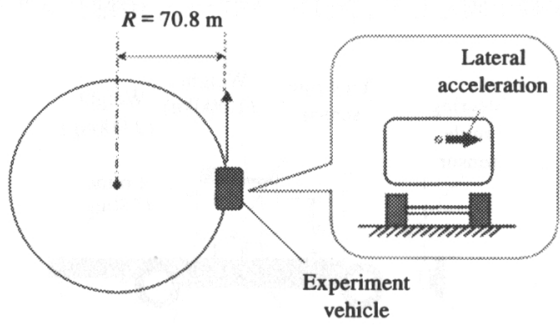

Fig. 3 Truck traveling at constant velocity and turning radius
験車両を傾斜台上に置き, 傾斜角 $\theta$ を段階的に増加さ せることにより車体に加わる横向き加速度 $a_{a c c}$ を模擬 し，その際のロール角を測定する. $a_{a c c}$ は $g \sin \theta$ で求 める. 定常円旋回実験では一定の旋回半径で実験車両 を走行させ, 速度を段階的に増加させることにより横 向き加速度を得る. 二つの実験の目的は同一である が，傾斜台実験ではドライバに危険がおよばないた め, より大きな横向き加速度を再現可能である.

$3 \cdot 2$ レーンチェンジ実験積載状態が動的な 車両状態量へ与える影響の解析のために, 実際の交通 環境下に近いクローズドループ実験として, 定速走行 でのレーンチェンジ実験を行う. 図 4 のように $50 \mathrm{~m}$ 進む間に $3.6 \mathrm{~m}$ 側方に車線変更するときのハンドル 操舵角, 重心位置のヨー角, ヨーレイト, ロール角, 横向き加速度を測定する. また, 走行速度と横速度を 測定し車体横滑り角を算出する. 走行速度は非積載時 で $60,80,100 \mathrm{~km} / \mathrm{h}$, 積載時で $60,80,90 \mathrm{~km} / \mathrm{h}$ とし, 左右のレーンチェンジを同一条件につき 3 回行 う. 図5はレーンチェンジ実験における時系列応答の 例である. 本研究では, レーンチェンジ時の入力舵角

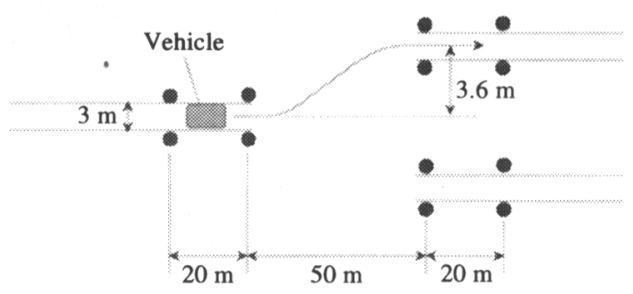

Fig. 4 Lane-change course

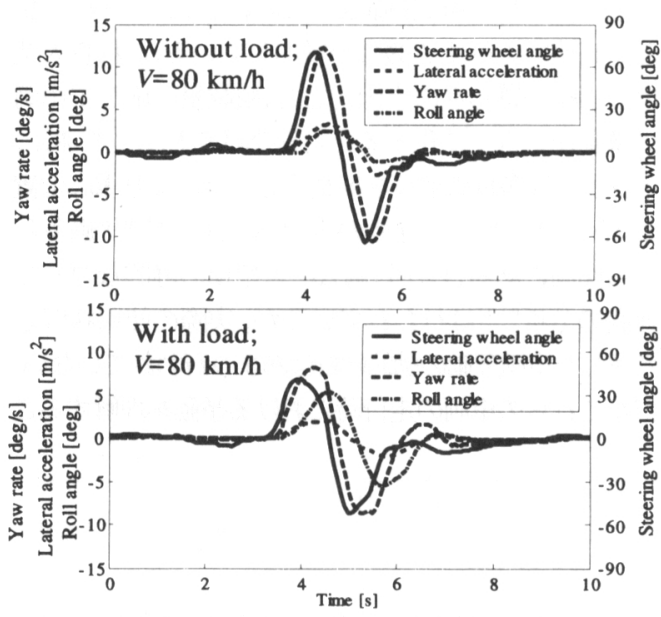

Fig. 5 Example of lane change maneuver data 


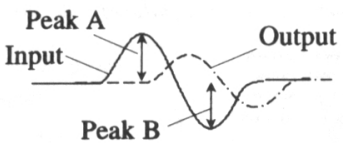

Fig. 6 Definitions of the peaks

と各出力变数の関係をより明確にするため, 図6に示 すように時系列応答のハンドル切り込み時のピークを ピーク A, 切り戻し時をピーク B と定義し, 各変数に おけるピーク A， B の大小に注目する.

$3 \cdot 3$ ランダム操论入力実倹図 5 において, 八 ンドルへの入力周波数は $0.5 \mathrm{~Hz}$ 前後である.つまり， レーンチェンジ実験では特定の入力周波数においての み車両運動の解析が可能である. そこで車両応答の周 波数特性を求めるためランダム操舵入力実験を行う. $80,100,120 \mathrm{~km} / \mathrm{h}$ で定速走行中にドライバが図7の ようなランダム操舵入力を加え, その際の入力舵角, 重心位置のヨーレイト, ロールレイト, 横向き加速度

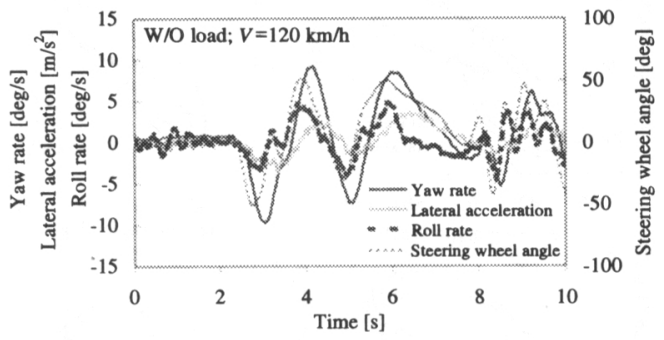

Fig. 7 Example of random steering input
を同条件で $3 \sim 4$ 回測定する. その結果からフーリエ 解析によりハンドル操舵角に対する各変数の周波数応 答のグラフを求める. また, 大型車ではフレームのね じり剛性が比較的低いため, 車両の前後でロール角が 異なり，危険な状態になるまで運転者が車体のロール 運動を把握できない場合がある. そこで，ロールレイ 卜のみ車体重心位置に加え前後車軸上で測定し, 測定 位置によるロール運動の差を検討する。

\section{4. 実医㰴果}

4・1 静的およひ動的解析によるロ一ル角 図8 に傾斜台, 定常円旋回, レーンチェンジ実験における 実験車両の各平面運動に対するロール角の測定値のグ ラフを示す。横軸は図 8(a) が横滑り角, (b) がヨーレ イト，(c) が横向き加速度, 綐軸は全てロール角であ る.レーンチェンジ実験による測定值は図6で定義し たピーク A， B の值を用いる. これらのグラフより， ロール角の測定值は各平面運動の出力值と共に増加し ているが, 特にヨーレイトと横向き加速度に対して明 確に線形関係を示していることがわかる. 一方，ロー ル角と横滑り角の関係に関しては計測值のばらつきが 大きく, 両者の関係はそれほど明確でない. また,ロー ル角の測定值を見ると積載時の方が非積載時に比較し 大きく増大している. さらに図8(b), (c)では非積載時 の測定值は実験方法にかかわらずほぼ同一線上に並ん でいるが, 積載時においては傾斜台, 定常円旋回実験 のような定常状態での実験によるロール角よりも， レーンチェンジ実験のように非定常状態で測定した
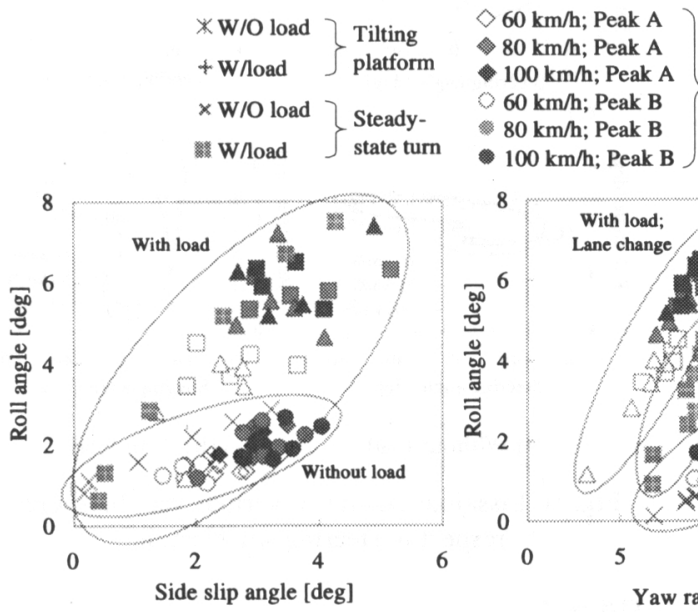

(a) Roll angle for given side slip angle

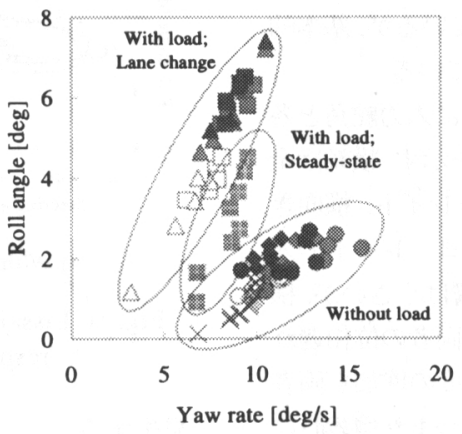

(b) Roll angle for given yaw rate
$60 \mathrm{~km} / \mathrm{h}$; Peak A

制 $80 \mathrm{~km} / \mathrm{h}$; Peak A

$90 \mathrm{~km} / \mathrm{h}$; Peak A Lane change

Lane change $160 \mathrm{~km} / \mathrm{h}$; Peak B with load

without load $\triangle 60 \mathrm{~km} / \mathrm{h}$; Peak B
$\therefore 80 \mathrm{~km} / \mathrm{h}$; Peak B

A $90 \mathrm{~km} / \mathrm{h}$; Peak B

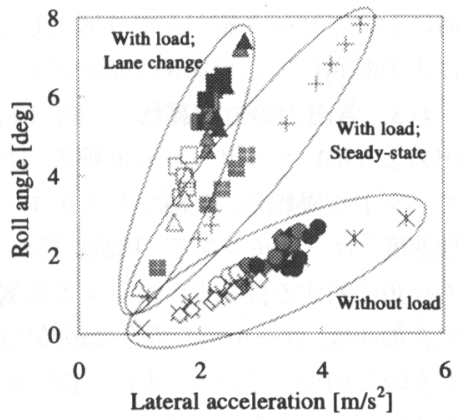

(c) Roll angle for given lateral acceleration

Fig. 8 Roll angle of experiment vehicle for given plane motion 
$660 \mathrm{~km} / \mathrm{h}$; w/o load $80 \mathrm{~km} / \mathrm{h}$; w/o load $\quad 100 \mathrm{~km} / \mathrm{h} ;$ w/o load $\Delta 60 \mathrm{~km} / \mathrm{h} ;$ w/load $\quad 40 \mathrm{~km} / \mathrm{h} ;$ w/load $\quad 90 \mathrm{~km} / \mathrm{h} ; \mathrm{w} / \mathrm{load}$
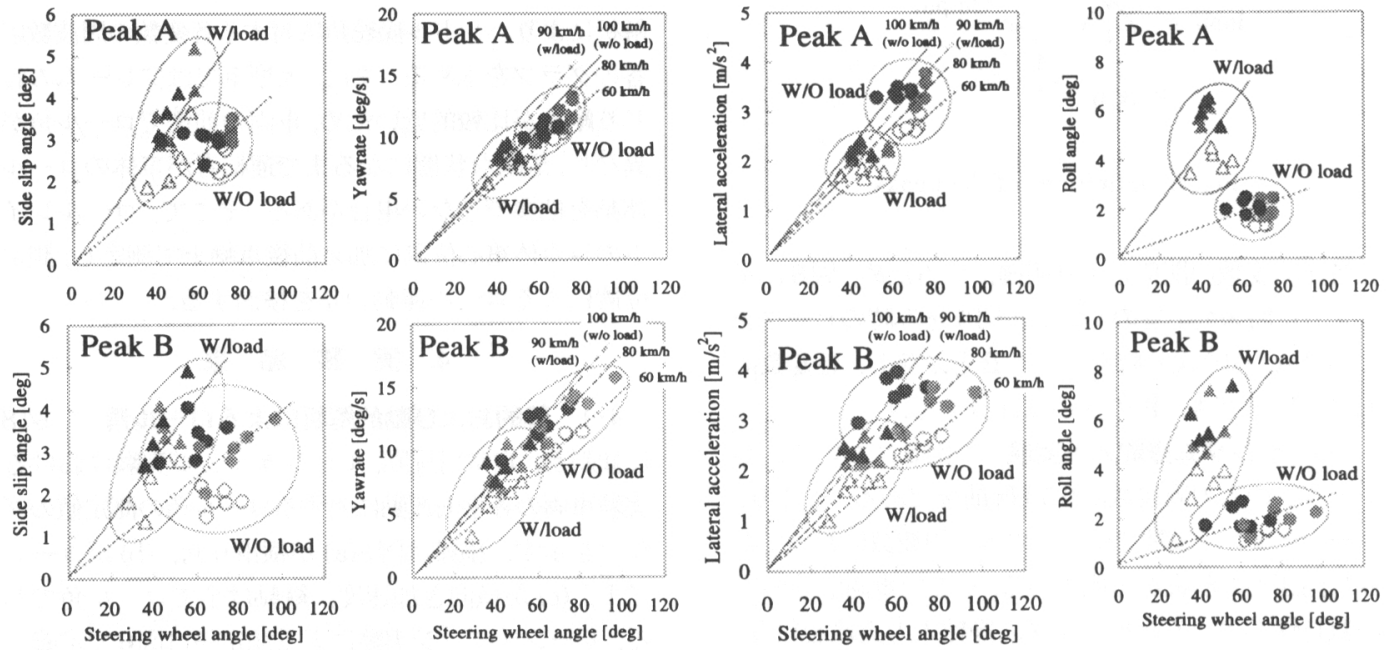

(a) Sideslip angle

(b) Yaw rate

(c) Lateral acceleration

(d) Roll angle

Fig. 9 Peak value of various output with respect to steering wheel angle

ロール角の方が大きくなっている.つまり, 積載時に レーンチェンジのように急激な危険回避を行った場 合, ロール角は定常值よりも大きな值を示す場合があ ることを意味する.

$4 \cdot 2$ 各出力のピーク值 図 $9(\mathrm{a}) \sim(\mathrm{d})$ にレーン チェンジ実験における, 入力舵角のピーク值に対する 各出力のピーク值を示す. グラフの横軸は全てハンド ル操舵角, 縦軸は図9(a) が横滑り角, (b) がヨーレイ 卜，(c) が横向き加速度，(d) がロール角である. 横滑 り角は測定值のばらつきが大きく, 他の出力に比較し 操舵入力との関係が明確でないことがわかる。 また, ヨーレイトは積載状態にかかわ加ず入力舵角に対して ほぼ同様の線形関係を持っている. 横向き加速度も同 様の特性を見せるが, 速度による測定值のばらつきが 特に積載時のピークBで顕著である. ロール角は積載 時においてピーク值がかなり増大しているが, 基本的 に入力舵角に対して比例関係を示している.

4.3 各出力の位相退れ 図 10 に入力舵角と各 出力より描いたリサージュ曲線の例を示す. 横軸は全 てハンドル操舵角, 縦軸は上よりヨーレイト, 横向き 加速度, ロール角である. 積載状態がヨーレイトの入 力舵角に対する位相遅れに与える影響は小さいが, 横 向き加速度, ロール角の場合積載時に両者の位相遅れ が大幅に増加している. また, 走行速度の増加も両者 の位相遅れを増大させる傾向にある.つまり積載時に 高速でレーンチェンジを行うと,ハンドル操舵に対し てロール角, 横向き加速度のピーク值は大きく遅れて
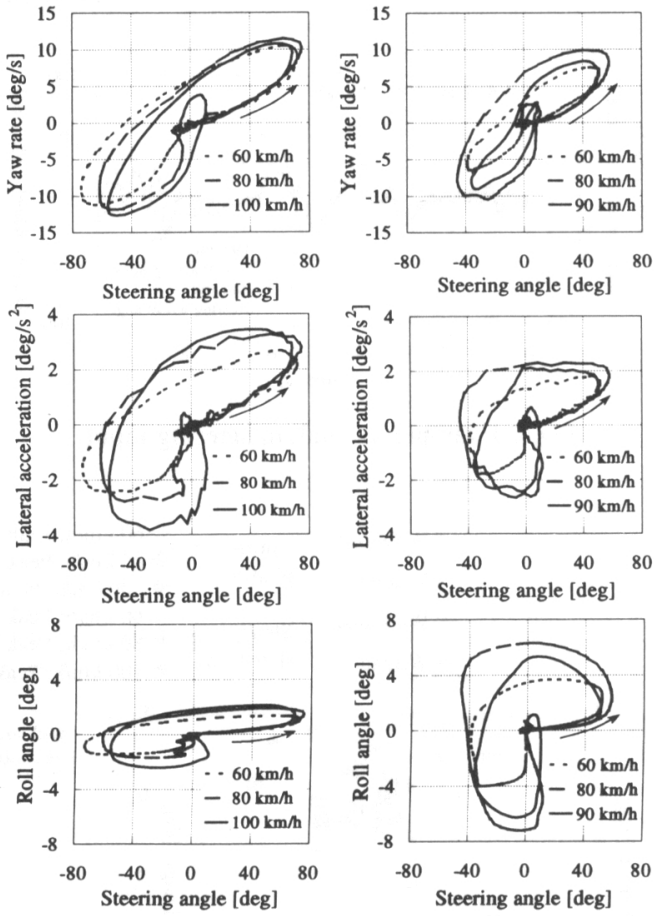

(a) Without load

(b) With load

Fig. 10 Lissajous figures of various variables with respect to steering wheel angle

発生する.

4-4 周波数応答 ランダム操舵実験より求めた ハンドル操舵角に対するヨーレイト, 横向き加速度, 
ロールレイトの周波数応答をそれぞれ図11〜13に示 す.積载状態が变化してもヨーレイトの周波数応答に は大きな影鳘は見られない. 一方, ロールレイトは積 载量が増加すると広い周波数域で大幅にゲインが増大
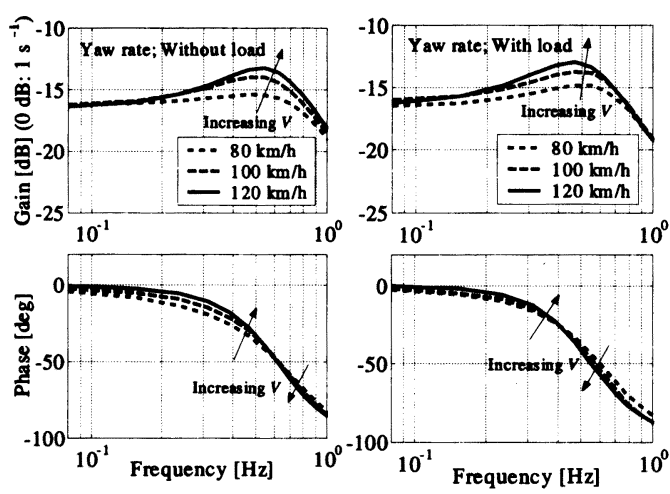

Fig. 11 Frequency response of yaw rate with respect to steering wheel angle (averaged)
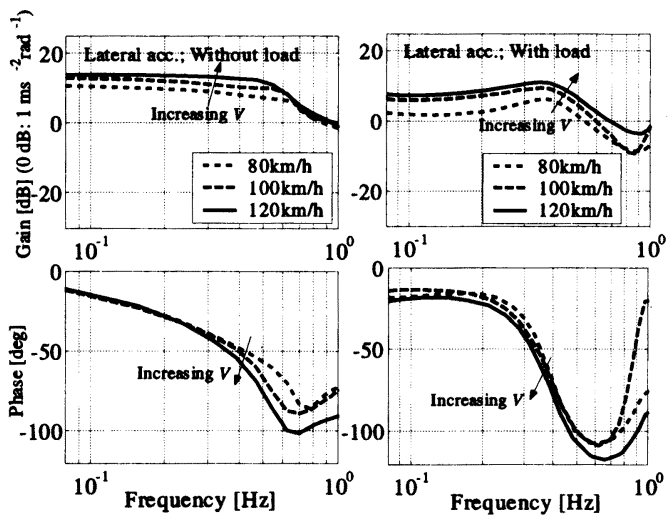

Fig. 12 Frequency response of lateral acceleration with respect to steering wheel angle (averaged)
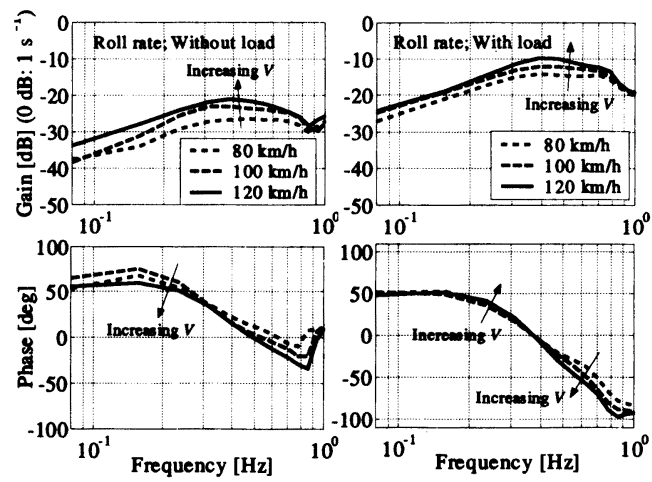

Fig. 13 Frequency response of roll rate with respect to steering wheel angle (averaged)
し，位相遅れも増えることがわかる．また，横向き加 速度は積㦲時にゲインが诚少し，位相遅れは高周波数 域て増加している.

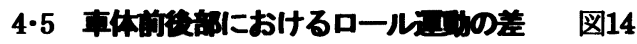
に前車軸上, 車体重心位置, 後車軸上で測定したロー ルレイトのハンドル揊拕角に対する周波数応答を示す.
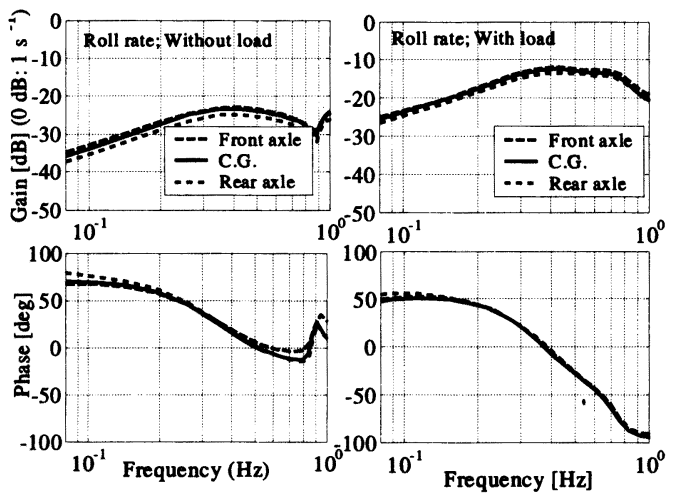

Fig. 14 Frequency response of roll rate at various locations of vehicle with respect to steering wheel angle $(V=100 \mathrm{~km} / \mathrm{h}$; averaged $)$

測定位置によるロール運動にはほとんど差が見られな い,つまり実験車両では，運転席と車体後部における ロール運動の差は小さいことがわかる.

\section{5. 車两远秋モデル}

ここでは,ロール運動が実験車両の平面運動に与え る影響をより明確にするため, 実験車両と同一の諸元 を持ち平面運動のみで構成される車両モデルと,ロー ル運動も含めたモデルでレーンチェンジのシミュレー ションを行い,レーンチェンジ実験の結果と比較する. 平面運動のみのモデルとして, 車両横滑り角とヨーレ イトを自由度とする等価二輪モデルを用いる.ロール 運動の自由度を含めたモデルには, 等価二輪モデルに ロール角を追加した三自由度モデルを用いる，なお， 実験車両のシャシのねじり剛性によっては前後部で異 なるロール角を持つ四自由度モデルの使用も考えられ るが(7), 前章で車体前後部におけるロール運動の差は 小さいことがわかっているので, 本研究では三自由度 モデルを用いる．各モデルの概要を図 15 に，運動方 程式を式(1)〜 (5) に示す.

\section{等価二輸モデル}

[横方向の運動方程式]

$$
m V(\dot{\beta}+r)=2 Y_{f}+2 Y_{r}
$$




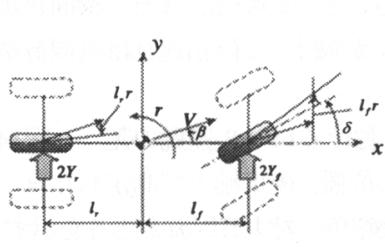

(a) Two-DOF "bicycle" model

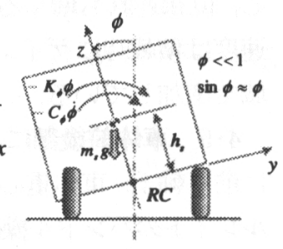

(b) Supplement for 3DOF model

Fig. 15 Vehicle models

最低および最高速度での結果を表示する. 等価二輪モ デルの場合, 非積載時かつ低速走行時は実車の平面運 動をよく再現できているが, 走行速度の増加と共にモ デルによる横向き加速度と実験值の間に差異が生じる. また, 積載時では車速にかかわらず実験值との差がか なり大きい. 三自由度モデルの場合, 積載時に実験值 との差異がわずかに増加するが, 等価二輪モデルに比 較し平面運動を正確に再現できている. だがロール角 は実験値と振幅, 位相が異なり, ロール運動のモデリ

\section{Experiment $\longrightarrow$ 3-DOF model --- 2-DOF model}
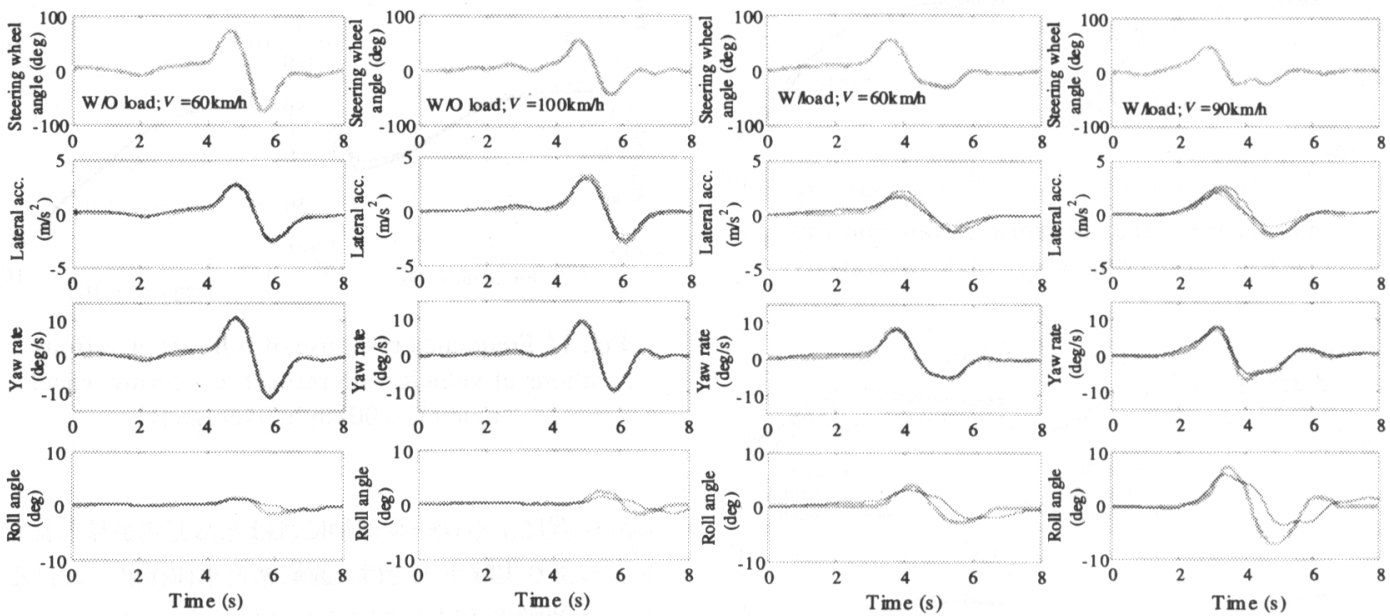

Fig. 16 Evaluating dynamic models using experiment data for lane change maneuver

[ヨー方向の運動方程式 $]$

$$
I \dot{r}=2 l_{,} Y_{f}-2 l_{r} Y_{r}
$$

三自由度モデル

[横方向の運動方程式］

$$
m V(\dot{\beta}+r)-m_{s} h_{s} \ddot{\phi}=2 Y_{f}+2 Y_{r}
$$

[ヨー方向の運動方程式 $]$

$$
I \dot{r}=2 l_{f} Y_{f}-2 l_{r} Y_{r}
$$

[ロール方向の運動方程式

$$
I_{\phi} \ddot{\phi}-m_{s} h_{s} V(\dot{\beta}+r)=\left(-K_{\phi}+m_{s} g h_{s}\right) \phi-C_{\phi} \dot{\phi}
$$

各記号の定義を表 1 に記す. 両モデルにおける夕 イヤモデルは, 式(6), (7) の線形タイヤモデルを 使用する.

[線形タイヤモデル]

$$
\begin{gathered}
Y_{f}=-k_{f}\left(\beta+l_{f} r / V-\delta\right) \\
Y_{r}=-k_{r}\left(\beta-l_{r} r / V\right)
\end{gathered}
$$

図 16 にレーンチェンジ時における時系列応答の，実 験値とモデルによる計算値の比較例を示す.レーン チェンジ実験は三通りの走行速度で行ったが, その内
ング方法に検討が必要である.

\section{6. 車两通耐モデルの理詥的罚析}

ここではトラックのロール運動と平面運動の連成に 関して, 前章の車両運動モデルを用いて理論的考察を 行う. 図 17 は今回使用した車両モデルの概要を示す

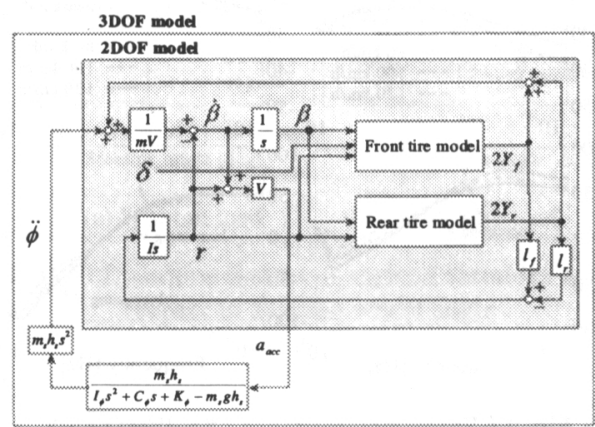

Fig. 17 Block diagram of dynamic models 
ブロック線図である. この図より, 等価二輸モデルで は平面運動に関するパラメータのみにより車両運動が 決定するが，三自由度モデルでは横向き加速度 $a_{a c c}$ が ロール角 横滑り角 $\beta$ にフードバックされる. そしてこの連成 は車両速度 $V$, ばね上重量 $m_{s}$ およびロールモーメン トアーム長 $h_{s}$ の増加と共に顕著となることがわかる. よって積載時に車両ロール角が大幅に増大し, また等 価二輪モデルが高速走行およひ積載時において実車の 平面運動を再現できない傾向が説明できる.さらに， 横向き加速度 $a_{a c c}$ は $V(\dot{\beta}+r)$ としても表されるので, 常に $\dot{\beta}$ が小さいと仮定すると第四章でロール角 $\phi$ が ヨーレイト $\boldsymbol{r}$ と横向き加速度 $\boldsymbol{a}_{a c c}$ に対してほぼ同様な 線形関係を示すことも説明できる. なお実際の車両で は,ロール運動と平面運動は図17の要素の他にもロー ルステアやキャンバスラスト, ばね上の慣性乗積, 夕 イヤの非線形性などを介して連成しているが, それら を考虑しなくても実験車両の平面運動をある程度再現 することができた.

\section{7. 结 言}

使用状況において変化するトラックの積載状態が, 車両の運動特性に与える影響を解析するため, 今回二 通りの積载状態の実験車両を用い, 静的およひ動的実 験を行った. その結果, 実験車両のロールと平面運動 の特性およびそれらの連成について次の点が明らかに なった.

・平面運動は積載状態の影響をそれほど受けないが, ロール運動はゲイン,位相遅れ共に積載時に大きく 增加する.
・車両ロール角は, ヨーレイトおよび横向き加速度に 強く影響を受ける.

・積载時の車両は,レーンチェンジのような動的状態 において, 定常時より大きいロール角を生じる場合 がある.

- ロール角と横向き加速度は, 積載時および高速走行 時に揊舵入力に対する遅れが大きい.

・ロール角は車両速度, ばね上重量, ロールモーメン トアーム長の影響を強く受ける.

\section{文南}

（1）西田外志男・吉崎良和・中林孝夫，トラックの操従性安定 性に及ほす路面の影繁について, 自動車技術, 46-3 (1992), 35-41.

（2）波多野忠・谷口哲夫・山元克毅・柳沢治茂，货物自動車の 程载位圈による走行安定性への影舫, 交通安全公害研究所 研究発表会講演概要, Vol. 30, (2000-11), 69-72.

（3）中川邦夫・西田恒明・大崎正喜，操安性に及ほすロール特 性の影管，自動車技術，43-3 (1989), 68-73.

（4）硧口実・種子田和宏・芝端康二・皆川正明，ばね上挙動が 車両運動性能に与える影管一第1 報: 動的なロール挙動と 操舵応答特性一, 自動車技術会学術講演会前刷集, No.107-01, (2001-10), 15-18.

(5) Ervin, R.D., The Influence of Size and Weight Variables on the Roll Stability of Heavy Duty Trucks, SAE Paper, 831163 (1983).

(6) Winkler, C.B., Karamihas, S.M. and Bogard, S.E., RollStability Performance of Heavy-Vehicle Suspensions, SAE Paper, 922426 (1992).

(7) Takano, S. and Masao, N., Dynamics Control of Large Vehicles for Rollover Prevention, Proc. IEEE Int 1 Vehicle Electronics Conf. 2001 (2001-9), 85-89. 